\title{
PROFIL PEMERIKSAAN SEDIMEN URINE PADA PASIEN TUBERCULOSIS DI BALAI KESEHATAN PARU MASYARAKAT MAKASSAR (BKPPM)
}

\author{
Profile Of Examination on Urine Sediment Examination Results in Tuberculosis \\ Patients at Makassar Public Lung Health Center (BKPMM) \\ ${ }^{1}$ Widarti, ${ }^{2}$ Zulfian Armah, ${ }^{3}$ Herman, ${ }^{4}$ Sri Rahayu \\ 1,2,3,4 Politeknik Kesehatan Kemenkes Jurusan Analis Kesehatan Makassar
}

Koresponden :sri_rahayu_2016@poltekkes-mks.ac.id

\begin{abstract}
Tuberculosis is a direct infectious disease caused by MTB (Mycobacterium tuberculosis) which has been treated using antibiotics. The use of antibiotics in a long time can cause side effects. Urine sediment examination is an important examination to determine the presence of kidney or urinary tract abnormalities as well as the severity of a disease. This study aims to find a picture of the results of urine sediment examination in tuberculosis patients. This research was conducted at the Makassar Public Lung Health Center (BKPMM) on April 2020. This type of research is descriptive. The number of samples in this study were 16 samples of tuberculosis patients, using secondary data from patirnt examination results. The research data were analyzed descriptively and presented in tabular form with narration. After conducting the research, it obtained a variation that is representative of the results of urine sediement examination of tuberculosis patients with the average examination results are still in normal status. For tuberculosis cases it is very important to monitor the patient's condition with regular health checks to monitor the success of the treatment.

Keywords : Antibiotics, Tuberculosis, Urine sediment
\end{abstract}

\begin{abstract}
ABSTRAK
Tuberculosis adalah penyakit menular langsung yang disebabkan oleh kuman MTB (mycobacterium tuberculosis) yang selama ini diatasi dengan menggunakan antibiotik. Penggunaan antibiotik dalam jangka waktu yang lama dapat menimbulkan efek samping. Pemeriksaan sedimen urine merupakan pemeriksaan yang penting untuk mengetahui adanya kelainan ginjal atau saluran kemih serta berat ringannya suatu penyakit. Penelitian ini bertujuan untuk mengetahui gambaran hasil pemeriksaan sedimen urine pada pasien tuberculosis. Penelitian ini dilaksanakan di Balai Kesehatan Paru Masyarakat Makassar (BKPMM) pada bulan april 2020. Jenis penelitian adalah deskriptif. Jumlah sampel dalam penelitian ini adalah 16 sampel pasien tuberculosis, dengan menggunakan data sekunder hasil pemeriksaan pasien.Setelah dilakukan penelitian, didapatkan variasi yang representatif terhadap hasil pemeriksaan sedimen urine pasien tuberculosis dengan ditemukannya beberapa unsur sedimen dalam urine seperti unsur organik : eritrosit, leukosit, epitel dan unsur anorganik yakni Kristal oksalat dengan rata-rata hasil pemeriksaan masih berada dalam status normal yang merepresentasikan status klinis pasien. Untuk kasus tuberculosis sangat penting untuk memantau kondisi pasien dengan pemeriksaan kesehatan secara berkala untuk memantau keberhasilan pengobatan.

Kata kunci : Antibiotik, Tuberculosis, Sedimen urine
\end{abstract}

Vol. 12 No. 1, Juni 2021

DOI: https://doi.org/10.32382/mak.v11i1.1517 


\section{PENDAHULUAN}

Indonesia adalah salah satu negara tropis. Sepanjang sejarah, wilayah tropis lebih mudah terjangkit penyakit menular dibandingkan dengan wilayah beriklim sedang. Penyebab utamanya adalah faktor lingkungan dimana wilayah tropis memiliki kelembaban cukup tinggi dan pertumbuhan biologis sebagai pendukung keanekaragaman hayati yang tinggi termasuk patogen, vektor, dan hospes. Hal ini diperparah oleh faktor kesadaran masyarakat dan pengendalian penyakit menular atau penyakit tropis yang kurang optimal (Skolnik dan Ambareen, 2010).

Infeksi tuberculosis masih menjadi masalah bagi sepertiga populasi dunia. Tuberkulosis merupakan penyebab utama kematian oleh infeksi dengan peringkat diatas penyakit human immunodeficiency virus (HIV). World Health Organization (WHO) pada tahun 2018 melaporkan sekitar 10 jutapenduduk dunia terinfeksi TB yang terdiri 5.8 jutalaki-laki, 3.2 juta perempuan, 1.0 juta anak-anak, dan9\% penderita HIV. Indonesia memiliki beban TB yangtertinggi ketiga di dunia dengan jumlah kasus TBsebanyak 842.000 kasus, dan insiden 319 kasus setiap100.000 penduduk. Insiden TB diharapkan menurunsekitar 4-5\% pertahun dan mencapai penurunan 10\%pada tahun 2020 sebagai tonggak dari end TB strategy (WHO, 2018)

Pada tahun 2015 jumlah penemuan kasus TB adalah 330.910 kasus. Jumlah tersebut meningkat dari tahun 2014, yaitu sebanyak 324.539 kasus. Kasus terbanyak dilaporkan di provinsi dengan jumlah penduduk terbesar yaitu jawa barat, jawa timur, dan jawa tengah (38\% dari keseluruhan kasus di indonesia). Berdasarkan jenis kelamin, jumlah kasus pada laki-laki adalah 1.5 kali dibandingkan perempuan berdasarkan kelompok usia pada tahun 2015 , terdapat $18,65 \%$ penderita berumur 25-34 tahun. 17,33\% penderita berumur 45-54 tahun dan 17,18\% penderita berumur 35-44 tahun.

Upaya untuk menurunkan angka kejadian yakni pemberian antibiotik seperti rifampisin, isoniazid, etambutol, streptomisin, dan pirazinamid yang telah dimanfaatkan selama bertahun-tahun sebagai anti $\mathrm{TB}$, namun sayangnya pengobatan dalam jangka waktu yang lama seringkali menimbulkan efek samping pada organ tertentu seperti gangguan fungsi ginjal serta resiko terjadinya resistensi obat. Sejak tahun 1980-an kasus tuberculosis di seluruh dunia mengalami peningkatan karena kemunculan MDR-TB (Multidrug Resisten Tuberculosis). (Chan dkk,2002)

Adanya potensi efek samping yang ditimbulkan oleh pengobatan tuberculosis tersebut, maka sangat perlu dilakukan pemeriksaan untuk memantaujalannya pengobatan terhadap pasien. Pemeriksaan sedimen urinemerupakan salah satu pemeriksaan yang bertujuan untuk mendeteksi kelainan ginjal dan saluran kemih, memantau hasil pengobatan serta skrining kesehatan secara umum. Pemeriksaan inidilakukan secara manual mikroskopik dan hasil dilaporkan secara semi-kuantitatif (Deni Ariffriana dkk, 2016).

Sejalan dengan penelitian Reviono, menunjukan hasil bahwa terapi antibiotik memberikan efek samping pada pasien salah satunya yakni indikasi kelainan fungsi ginjal serta penelitian serupa yang dilakukan oleh Pingkan C. Pasuhuk dkk, menunjukkan indikasi adanya indikasi penurunan kemampuan 
filtrasi glomelurus dengan ditemukannya leukosit dan eritrosit pada hasil pemeriksaan sedimen urine pasien tuberculosis.

\section{METODE}

Jenis penelitian ini merupakan penelitian deskriptif. Dengan dilakukan pemeriksaan laboratorium untuk mengetahui gambaran hasil pemeriksaan sedimen urine pada pasien Tuberculosis di Balai Kesehatan Paru Masyarakat Makassar pada bulan April 2020. Sampel pada penelitian ini adalah urine sewaktu dari semua pasien tuberculosis dewasa dalam kurun waktu dan kriteria yang telah ditentukan dengan teknik accidental sampling.

\section{HASIL}

Pada 16 sampel sedimen urine pada pasien tuberculosis ditemukan beberapa unsur sedimen organik maupun anorganik. Sedimen organik adalah eritrosit, leukosit, dan epitel, sedangkan sedimen anorganik yang ditemukan kristal oksalat.

Sedimen organik eritrosit pada 16 sampel hasilnya 15 sampel normal (94\%) dan 1 sampel abnormal (6\%), leukosit 15 sampel normal (94\%) dan 1 sampel abnormal(6\%) Untuk epitel 13 sampel normal ( 81\%)dan 3 sampel abnormal (19\%), untuk silinder 16 sampel normal (100\%). Sedimen anorganik 15 sampel normal (94\%) dan 1 sampel ditemukan oksalat $(6 \%)$

Pada hasil pemeriksaan eritrosit pada sedimen urine pasien tuberculosis yang diamati secara mikroskopis pada 16 sampel terdapat beberapa diantaranya menunjukan keadaan abnormal $(+,++,+++)$. Terdapat 1 sampel dalam jumlah abnormal (6\%) sedangkan 15 sampel lainnya masih dalam jumal normal $(94 \%)$.

\section{PEMBAHASAN}

Penelitan ini adalah penelitian yang bertujuan untuk melihat gambaran hasil pemeriksaan sedimen urine pada pasien tuberculosis di Balai Kesehatan Paru Masyarakat Makassar (BKPMM).

Pemeriksaan sedimen urine atau disebut juga mikroskopik urine merupakan pemeriksaan lanjutan setelah kimia urine, yang penting untuk mengetahui adanya kelainan ginjal atau saluran kemih serta berat ringannya suatu penyakit. Pemeriksaan sedimen ini biasanya menggunakan urine sewaktu atau urine pagi, setelah mengumpulkan urine segera dilakukan pemeriksaan karena penundaan pemeriksaan tanpa diberikan pengawet dapat menyebakan terjadinya perubahan pada komposisi zat dan hasil yang dikeluarkan seperti pertumbuhan bakteri, kadar glukosa menurun, PH menjadi alkalis, dekomposisi silinder, lisisnya eritrosit, perubahan bentuk leukosit (rusak), urine menjadi makin keruh, perubahan warna dan bau, serta nitrit menjadi positif. (Ruth mongan dkk,2017)

Pada pemeriksaan sedimen urine pasien tuberculosis di Balai Kesehatan Paru Masyarakat Makassar (BKPMM), di peroleh variasi gambaran sedimen yang merupakan indikasi kesehatan serta pemberian terapi obat anti tuberculosis. Pengamatan sedimen tergantung apa yang terdapat di dalam urine normal, dan bisa di idetifikasi secara akurat dengan membandingkan antara hasil normal dan abnormal. Munculnya beberapa partikel maupun unsure tertentu dalam urine mungkin normal, hal ini dapat berupa sel-sel darah, selsel yang melapisi saluran kencing (epitel squamous), partikel protein silinder yang telah terbentuk di nefron (gips), Kristal yang terbentuk dalam urine, dan sel asing misalnya spermatozoa,

Vol. 12 No. 1, Juni 2021

DOI: $\underline{\text { https://doi.org/10.32382/mak.v11i1.1517 }}$ 
mikroorganisme,dankontaminan.Hasil penelitian menunjukan ditemukannya unsur-unsur sedimen baik organik maupun anorganik yang terdapat dalam urine pasien, seperti ; eritosit, leukosit, epitel, dan Kristal oksalat.

1) Eritrosit abnormal ditemukan pada 1 pasien (6\%) sedangakan 15 pasien (94\%) dalam keadaan normal. Eritrosit dalam air seni merupakan unsure yang berasal dari bagian manapun dari saluran kemih, mulai dari glomerulus hingga meatus uretra dan pada perempuan dapat berasal dari cemaran darah haid. Eritrosit ini dapat muncul dalam berbagai bentuk, bergantung pada keadaan lingkungan dalam air kemih. Bila spesimen air kemih segar, eritrosit tampak normal, berwarna kekuningan, permukaan licin, berbentuk bikonkaf berdiameter tujuh mikron dan ketebalan dua mikron. Eritrosit tidak memiliki inti dan bila terlihat dari samping, maka memiliki gambaran seperti jam pasir. Dalam air kemih yang hipotonik, eritrosit membengkak dan dapat mengalami lisis, kemudian melepaskan hemoglobin ke dalamnya. Eritrosit yang telah lisis ini disebut juga ghost cells/shadow cells, yang tampak sebagai lingkaran tidak berwarna dan membrane eritrosit yang kosong. Lisis eritrosit juga terjadi di air kemih yang alkalis. Pada air kemih yang hipertonik eritrosit akan mengerut dan terkadang kondisi ini menyerupai butiran. Secara teoritis, harusnya tidak dapat ditemukan adanya eritrosit, namun dalam urine normal dapat ditemukan $0-3$ sel/LPK. Hematuria adalah adanya peningkatan jumlah eritrosit dalam urin karena: kerusakan glomerular, tumor yang mengikis saluran kemih, trauma ginjal, batu saluran kemih, infeksi, inflamasi, infark ginjal, nekrosis tubular akut, infeksi saluran kemih atas dan bawah, nefrotoksin, dll.

Hematuria dibedakan menjadihematuriamakroskopik dan hematuria mikroskopik. Darah yang dapat terlihat jelas secara visual menunjukkan perdarahan berasal dari saluran kemih bagian bawah, sedangkan hematuria mikroskopik lebih bermakna untuk kerusakan glomerulus. Dinyatakan hematuria mikroskopik jika dalam urin ditemukan lebih dari 5 eritrosit/LPK. Hematuria mikroskopik sering dijumpai pada nefropati diabetik, hipertensi, dan ginjalpolikistik. Hematuria mikroskopik dapat terjadi persisten, berulang atau sementara dan berasal dari sepanjang ginjal-saluran kemih. Nilai rujukan dari Eritrosit yakni :

Normal: 0-3/LPB

Poitif satu (+): apabila di temuakan eritrosit4-8/LPB

Positif dua (++): apabila di temukan eritrosit8-30/LPB

Positif tiga $(+++)$ apabila ditemukan erirosit lebih dari 30/LPB

2) Leukosit abnormal ditemukan pada 1 pasien $(6 \%)$ sedangakan 15 pasien (94\%) dalam keadaan normal. leukosit sering di temukan pada sedimen urine normal, tetapi sedikit dan tidak melebihi 5/LPB. Walaupun semua jenis leukosit yang muncul dalam darah perifer juga di temukan dalam urine (yaitu limfosit, monosit, eosinofil), namun sel yang paling umum adalah Lekosit dalam urine umumnya adalah neutrophil (polymorphonuclear, PMN). PMN memiliki fungsi fagositosis motil 
secara aktif, dan bergerak secara amuboid dengan pseudopodia. PMN dalam urine dapat segera di ketahui inti multi segmennya dan sitoplasma granular. Lekosit berbentuk bulat, berinti, granuler, berukuran kirakira1,5 - 2 kali eritrosit.Lekosit dapat berasal daribagian manapun dari saluran kemih. Lekosit hingga 4 atau 5 perLPK umumnya masih dianggap normal.Suatu keadaan terdapatnya leukosit dalam urin yangmelebihi nilai normal disebutleukosituria. Leukosituria merupakansalah satu tanda adanya peradangan pada saluran kemih (mencakupginjal, ureter, kandung kemih, dan uretra). Leukosituria dikatakanbermakna bila ditemukan > 10 leukosit/LPB pada sedimen urin.

Leukosituri dapat terjadi pada keadaan infeksi maupun inflamasisaluran kemih, seperti glomerulonefritis, pielonefritits, sistitis, uretritis, nefrolitiasis, urolitiasis, dll. Leukosituri sering menyertaiinfeksi saluran kemih. Jika bakteri tidak ditemukan (disebutleukosituria steril) maka harus dipertimbangkan adanya penyebablain seperti tuberkulosis saluran ginjal, kanker, dan batu ginjal atausaluran kemih.Leukosit diidentifikasi dari bentuknya yang bulat danberinti satu atau lebih, sitoplasma bergranula atau tanpagranula. Jika hasil pemeriksaan sedimen urin menunjukaan leukosituria bermakna perlu dievaluasi lebih lanjut untuk mencari tahu penyebab yang mendasarinya, apakah terdapat inflamasi atau infeksi pada saluran kemih penderita.Nilai rujukan leukosit yakni:

Normal: 0-4/LPB
Poitif satu (+): apabila di temukan leukosit 5-20/LPB

Positif dua (++): apabila di temukan leukosit 20-50/LPB

Positif tiga $(+++)$ apabila ditemukan leukosit lebih dari 50/LPB

3) Sel epitel abnormal ditemukan pada 3 pasien (19\%) sedangakan 13 pasien $(81 \%)$. Dalam keadaan normal urine normal berisi tiga varietas utama sel epitel: tubular ginjal, transisi (urothelial), dan squamos. Sel- sel ini melapisi saluran kemih, tubulus dan nefron. Sel epitel renal tubular jarang ada dalam sedimen urine yang normal (0-1/LPB). Bila ada, biasanya dalam bentuk tunggal tetapi juga di temukan berpasangan. Sel transisi merupakan lapisan epitel pada sebagian besar saluran kemih dan sering tampak di sedimen (01/LPB).Bentuknyabertingkattingkat dan biasanya dengan lapisan sel tebal dengan tiga bentuk utama yaitu bulat, polyhedral, dan kecebong. Sel epitel squamos adalah yang termudah dari semua sel epitel, dan mudah di kenali dan sering di jumpai dalam urine karena bentuknya yang besar dan datar, Spesimen urine porsi tengah paling baik di gunakan.sel-sel epitel dalam urine berasal dari lapisan system genitourinary. Sel epitel dapat dijumpai dalam jumlah besar atau normal yang merupakan pengelupasan dari sel-sel tua, merupakan epitel yang rusak dan pengelupasan yang disebabkan oleh proses inflamasi atau penyakit ginjal. Pelaporan hasil jika ditemukan epitel dalam urine $(+,++,+++)$ nilai normal jika ditemukan <10/LPB.

4) Ditemukan jenis Kristal okslat pada pasien dengan jumlahabnormal 
ditemukan pada 1 pasien $(6 \%)$ sedangakan 15 pasien $(94 \%)$ dalam keadaan normal. Kristal terbentuk berkaitan dengan konsentrasi berbagai garam di urine yang berhubungan dengan metabolism makanan pasien dan asupan cairan serta dampak dari perubahan yang terjadi dalam urine setelah koleksi sampel(yaitu perubahan $\mathrm{pH}$ dan suhu yang mengubah kelarutan garam dalam urine dan menghasilkan pembentukan kristal). Kristal kalsium oksalat paling sering ditemukan pada urine asam dan netral. Bentuk yang umum adalah bentuk dihidrat, Kristal berwarna mirip bentuk amplop. Kristal jenis ini di temukan dalam urine normal, yaitu terutama setelah mengkonsumsi asam askorbat dalam dosis besar atau makanan yang kaya akan asam oksalat.Mikroskop merupakan alat yang utama dalam penelitian sedimen urine ini. Mikroskop yang digunakan harus dengan lensa yang karena dapat mempengaruhi lapangan pandang pada saat pemeriksaan sedimen urine di bawah mikroskop. (Ruth mongan dkk,2017).

Hasil penelitian menunjukan sedimen urine pada pasien tuberculosis di Balai Kesehatan Paru Masyarakat Makassar (BKPMM) jumlah eritrosit normal pada 15 pasien (94\%) dan abnormal pada 1 pasien $(6 \%)$ yang diperiksa. Jumlah leukosit normal 15 pasien (94\%) dan abnormal 1 (6\%), epitel normal 13 pasien $(81 \%)$ dan abnormal 3 (19\%), Kristal normal pada 15 pasien (94\%) dan abnormal pada 1 pasien $(6 \%)$ ditemukan Kristal oksalat. Hasil pemeriksaan menunjukan tidak ditemukannya unsur sedimen lain seperti silinder, bakteri, dan sebagainya. Keterbatasan penelitian adalah kurangnya data pasien untuk mengetahui adanya riwayat penyakit penyerta pada pasien serta informasi mengenai waktu pengobatan pasien. Penelitian ini relavan dengan penelitian yang dilakukan oleh Pingkan C. Pasuhuk $\mathrm{dkk}$, menunjukkan adanya indikasi penurunan kemampuan filtrasi glomelurus pada ginjal dengan ditemukan adanya leukosit dan eritrosit pada hasil pemeriksaan sedimen urine pada pasien tuberculosis.

\section{KESIMPULAN}

Berdasarkan hasil penelitian di Balai Kesehatan Paru Masyarakat Makassar (BKPMM) pada bulan April 2020 dari 16 sampel diperoleh hasil penelitan yang menunjukan gambaran variatif yang representat terhadap gambaran hasil pemeriksaan sedimen urine pada pasien tuberculosis yang meliputi : unsur organik seperti eritrosit, leukosit, epitel, dan anorganik yaitu kristal oksalat.

\section{SARAN}

Disarankan untuk diteliti dengan sampel yang lebih besar.

\section{UCAPAN TERIMKASIH}

Diucapkan terimakasih pada Ketua Jurusan Analis Kesehatan dan semua pihak yang telah membantu dalam proses penelitian ini.

\section{DAFTAR PUSTAKA}

Abdallah, A.M., Gey van Pittius, N.C., Champion, P.A., Cox, J., Luirink, J., VandenbrouckeGrauls, C.M., Appelmelk, B.J. and Bitter, W., 2007, Type VII Secretion- 
Mycobacteria Show The Way, Nat. Rev. Microbiol.

Alimuddin, I., Zumla, Gillespie, G.S., Hoelscher, M., Philips, P.P.J., Cole, S.T., Ibrahim, A., McHugh, T.D., dkk., 2014, New Antituberculosis Drugs, Regimens, And Adjunct Therapies: Needs, Advances, and Future Prospects, www.thelancet.com/infectio $n$.

Bambang S, Ari FS. Urinalisis. Buku Ajar Ilmu Penyakit Dalam (6th ed). Jakarta Pusat: Interna Publishing, 2014.

CDC, 2016, Transmission and Pathogenesis of Tuberculosis, https://www.cdc.gov, 12 Oktober 2016.

Delogu, G., Sali1, M. \& Giovanni, F., 2013, The Biology of Mycobacterium Tuberculosis Infection, Mediterr J Hematol Infect.

Depkes RI, 2008, Pharmaceutical Care,

Direktorat Bina Farmasi

Komunitas dan Klinik, Direktorat Jenderal Bina Kefarmasian dan Alat Kesehatan Departemen Kesehatan RI,Jakarta.

Hardjoeno H. Interpretasi Hasil Tes Laboratorium Diagnostik Edisi 5.Lembaga penerbitan

Universitas Hasanuddin. 2003.

Hardjoeno, H. Fitriani, 2007. Subtansi

Dan Cairan Tubuh, lembaga penerbitan universitas hasanuddin.makassar.

Julius, M., Cruse, M.D., Robert, E., Lewis, 201@imamora V, Tjitrosantoso HM, Atlas of Immunology, 3th Ed., CRC Wiyono WI. Evaluasi Press, New York.

Kementerian Kesehatan Republik Indonesia, 2015, Rencana Strategis Kementerian
Kesehatan Tahun 2015-2019, Jakarta, Indonesia.

Kementerian Kesehatan Republik Indonesia, 2016, Profil Kesehatan Indonesia Tahun 2015, Jakarta, Indonesia.

Ma, Z., Ginsberg, A.M. \& Spigelman, 2007, Antimycobacterium Agents, Global Alliance for TB Drug Development, New York, USA..

Pingkan C Pasuhuk, Arthur E Mongan, Mayer Wowor. 2016. Gambaran Leukosit Urine Pada Pasien Tuberculosis Dewasa.Jurnal e-Biomedik (eBm), Volume 4, Nomor 2, Juli-Desember 2016.https://doi.org/10.3579 O/ebm.4.2.2016.14653

Purnomo B, Basuki. Dasar-Dasar Urologi. Edisi 2.Fakultas Kedokteran Universitas Brawijaya. Malang. 2007.

Ruth Mongan, Supiati, Susi Mangiri, 2017. Gambaran Sedimen Urin Pada Masyarakat Yang mengonsumsi Air Pegunungan di Kecamatan Kendari Barat Kota Kendari. Vol.6, No.1, Maret 2017, pp. 18 24 ISSN: 2338 - 5634 (print); ISSN: 2580-0191. https://teknolabjournal.com/i ndex.php/Jtl/article/view/88

Reviono, Harsini, Rohmat Andriyadi, Arif Hasanuddin. , 2018. Tuberculosis ; Unfinished Battle "Melawan Efek Samping pada Kasus TB Resisten Obat".

Wiyono WI. Evaluasi
penggunaan antituberkulosis pada pasien tuberkulosis paru di Instalasi Rawat Inap RSUP. Prof. Dr. R. D. Kandou Manado 
periode Januari - Desember 2010 [Skripsi]. Manado: Universitas Sam Ratulangi;

Steinhilber, D., Schubert-Zsilavecz, M., Roth, H. J., 2010, Medizinische Chemie, 2nd Ed., Deutscher Apotheker Verlag, Jerman.

Sri Melati Munir, Arifin Nawas, Dianiati K $\quad$ Soetoyo. 2010. Pengamatan Pasien Tuberkulosis Paru dengan Multidrug Resistant(TBMDR) Departemen Pulmonologi dan Ilmu Kedokteran Respirasi FKUIRS Persahabatan Jakarta. http://jurnal.farmasi.umi.ac.id lindex.php/assyifaa/article/view/15

Velayati, A.A. \& Parissa, F., 2016, Atlas of Mycobacterium Tuberculosis, Academic
Press, London, United Kingdom.

Vernon, A.A., 2003, Rifamycin Antibiotics, with A Focus on Newer Agents, dalam Rom, W.N., \& Garay, S.M., (Ed.), Tuberculosis, 2nd Ed., Lippincott Williams \& Wilkins, Philadelphia

World Health Organization, 2010, Treatment of tuberculosis, WHO guidelines, 4.ed.,(2010):http://whqlibdoc .who.int/publications/2010/9 789241547833_eng.pdf?ua $=1$ , 12 Oktober 2016

World Health Organization, 2011, Guidelines for Intensified Tuberculosis Case-Finding and Isoniazid Preventive Therapy for People Living with HIV in Resource Constrained Settings. 
Tabel 01: Hasil pemeriksaan sedimen urine

\begin{tabular}{|c|c|c|c|c|c|c|c|c|}
\hline \multirow[t]{2}{*}{ No. } & \multirow[t]{2}{*}{ Pasien } & \multicolumn{6}{|c|}{ Hasil Pemeriksaan } & \multirow[t]{2}{*}{ Ket. } \\
\hline & & Eritrosit & Leukosit & Epitel & Silinder & Kristal & Lainnya & \\
\hline 1 & $\begin{array}{l}\text { Tn.AM } \\
\text { (L/41) }\end{array}$ & $0-1$ & $1-2$ & 5 & Neg & $\mathrm{Neg}$ & Neg & - \\
\hline 2 & $\begin{array}{l}\text { Ny.Y } \\
(\mathrm{P} / 23)\end{array}$ & $2-3 *$ & $3-4 *$ & 12 & $\mathrm{Neg}$ & Neg & Neg & - \\
\hline 3 & $\begin{array}{c}\text { Tn.ASA } \\
\text { (L/42) }\end{array}$ & $0-1$ & $1-2$ & 4 & $\mathrm{Neg}$ & Neg & Neg & - \\
\hline 4 & $\begin{array}{c}\text { Tn.AM } \\
\text { (L/39) }\end{array}$ & $0-1$ & $1-3$ & 10 & $\mathrm{Neg}$ & $\mathrm{Neg}$ & Neg & - \\
\hline 5 & $\begin{array}{c}\text { Tn.D } \\
(\mathrm{L} / 41)\end{array}$ & $0-1$ & $1-2$ & 5 & $\mathrm{Neg}$ & Neg & Neg & - \\
\hline 6 & $\begin{array}{l}\text { Tn.EW } \\
\text { (L/32) }\end{array}$ & $0-1$ & $1-2$ & 5 & $\mathrm{Neg}$ & Neg & Neg & - \\
\hline 7 & $\begin{array}{c}\text { Tn.F } \\
(\mathrm{L} / 52) \\
\end{array}$ & $0-1$ & $1-2$ & 9 & $\mathrm{Neg}$ & $\mathrm{Neg}$ & Neg & - \\
\hline 8 & $\begin{array}{c}\text { Ny.ZDD } \\
(\mathrm{P} / 28)\end{array}$ & $0-1$ & $1-2$ & 4 & $\mathrm{Neg}$ & Neg & Neg & - \\
\hline 9 & $\begin{array}{c}\text { Tn.HM } \\
\text { (L/31) }\end{array}$ & $0-1$ & $1-3$ & 6 & $\mathrm{Neg}$ & $\mathrm{Neg}$ & Neg & - \\
\hline 10 & $\begin{array}{c}\text { Ny.NSP } \\
(\mathrm{P} / 29)\end{array}$ & $0-1$ & $2-4 *$ & 8 & $\mathrm{Neg}$ & Neg & Neg & - \\
\hline 11 & $\begin{array}{l}\text { Ny.RY } \\
(\mathrm{P} / 26)\end{array}$ & $0-1$ & $1-2$ & $12 *$ & $\mathrm{Neg}$ & $\mathrm{Neg}$ & $\mathrm{Neg}$ & - \\
\hline 12 & $\begin{array}{c}\text { Tn.A } \\
\text { (L/36) }\end{array}$ & $0-1$ & $1-2$ & 8 & $\mathrm{Neg}$ & $\mathrm{Neg}$ & Neg & - \\
\hline 13 & $\begin{array}{l}\text { Ny.RF } \\
(\mathrm{P} / 40)\end{array}$ & $0-1$ & $1-2$ & 8 & Neg & Neg & Neg & - \\
\hline 14 & $\begin{array}{c}\text { Tn.ABS } \\
\text { (L/42) }\end{array}$ & $0-1$ & $1-2$ & 3 & Neg & Neg & Neg & - \\
\hline 15 & $\begin{array}{l}\text { Tn.JG } \\
\text { (L/25) }\end{array}$ & $\mathrm{Neg}$ & Neg & Neg & Neg & Neg & Neg & - \\
\hline 16 & $\begin{array}{c}\text { Tn.MN } \\
\text { (L/44) }\end{array}$ & $5-10$ & $15-20$ & $10-15$ & Neg & $\begin{array}{l}\text { 15-20 } \\
\text { Kristal } \\
\text { Oksalat }\end{array}$ & Neg & - \\
\hline
\end{tabular}

Tabel 02 : Diagnosa klinis hasil pemeriksaan sedimen urine.

\begin{tabular}{cccccc}
\hline \multirow{2}{*}{ No. } & \multirow{2}{*}{ Jenis Sedimen } & \multicolumn{2}{c}{ Normal } & \multicolumn{2}{c}{ Abnormal } \\
\cline { 3 - 6 } & & $\mathbf{N}$ & $\mathbf{\%}$ & $\mathbf{N}$ & $\%$ \\
\hline 1. & Eritrosit & 15 & $94 \%$ & 1 & $6 \%$ \\
\hline 2. & Leukosit & 15 & $94 \%$ & 1 & $6 \%$ \\
\hline 3. & Epitel & 13 & $81 \%$ & 3 & $19 \%$ \\
\hline 4. & Silinder & - & - & - & - \\
\hline 5. & Kristal & 15 & $94 \%$ & 1 & $6 \%$ \\
\hline 6. & Lainnya & - & - & - & - \\
\hline
\end{tabular}


ISSN : 2087-1333 (Online) 